\title{
DOI 10.15393/j9.art.2014.751
}

\section{Любовь Викторовна Алексеева}

специалист жеb-лаборатории филологического факультета, мл. науч. сотрудник каф. русской литературы и журналистики, Петрозаводский государственный университет (Петрозаводск, Российская Федерация) lempi@mail.ru

\section{ОБРАЗЫ СТАРООБРЯДЦЕВ В ДИЯОГИИ П. И. МЕ АЬНИКОВА-ПЕЧЕРСКОГО «В ЛЕСАХ» И «НА ГОРАХ»*}

Аннотация. Статья посвящена рассмотрению архетипа праведника в дилогии П.И. Мельникова-Печерского на примере образов старообрядцев, которые занимают основную часть художественного текста. На примере темы праведничества показана связь дилогии П.И. Мельникова-Печерского с традициями древнерусской литературы, ориентированной на христианские ценности. Русская литература XIX века, сохранившая эти традиции, обращаясь к теме праведничества, создала героя нового типа. Это мирские люди, неидеальные, небезгрешные, но сохранившие память об идеалах Древней Руси. Такие герои-праведники, воплощающие в себе добродетели, представлены в дилогии П.И. Мельникова-Печерского. В статье проводятся типологические параллели с древнерусской литературой, а также выделяются несколько типов героев-праведников в дилогии: типы праведных жен и духовных странников. На основе анализа художественных образов старообрядцев делается вывод о том, что главным критерием праведничества для П.И. Мельникова-Печерского становится не принадлежность героя к старообрядчеству или господствующей церкви, а его христианское мироощущение, следование евангельским заветам. Поэтому П. И. Мельников-Печерский не делает своих героев-праведников из старообрядцев активными выразителями старообрядческой идеологии.

Ключевые слова: образ, старообрядец, праведник, традиция, древнерусская литература, национальный идеал, духовные ценности

$\mathrm{O}$ бразы старообрядцев в дилогии П.И. Мельникова-Печерского «В лесах» $(1871-1874)$ и «На горах» $(1875-1881)$ представляют совершенно особую систему, созданную автором вопреки сложившейся в литературе обличительно-сатирической традиции изображения старообрядчества, приверженцем которой долгое время был и сам автор («Поярков», 1857; «Гриша», 1860). Вопреки этой традиции, П.И. Мельников-Печерский показал в старообрядческой среде не просто положительные образы, но образы, обращенные 
к национальным истокам, воплощающие духовные ценности народа. На связь дилогии с национальной жизнью, духовно-нравственными идеалами, традициями древнерусской культуры указывали многие исследователи: В.В. Боченков [1], [2], Н.Г. Дергунова [4], И. В. Кудряшов [6], [7], В.А. Липатов [9], Е. В. Николаева [12], С. А. Тарасова [16], С. С. Царегородцева [20] и др.

Значительный пласт дилогии, вершины творчества П.И. Мельникова-Печерского, составляют герои праведнического типа. Особенность раскрытия П.И. Мельниковым-Печерским темы праведничества в том, что герои-праведники показаны как среди старообрядцев Заволжья, которым посвящена дилогия, так и среди представителей господствующей церкви («великороссийской», «никониан») и в народной среде, соединяющей православное и языческое начало. Данная статья посвящена образам праведников-старообрядцев.

Следует отметить то, что образы праведников активно входят в русскую литературу 2 пол. XIX века, традиционно ориентированную на христианские ценности. Тема праведничества была широко раскрыта в произведениях таких писателей XIX века, как Н. С. Лесков, Н. А. Некрасов, Ф. М. Достоевский, Л.Н. Толстой и др., а затем продолжена писателями XX века (В. Шукшин, В. Белов, В. Астафьев, В. Распутин, А. Солженицын) [18], [19], [8], [14], [15]. Русская литература XIX века, обращаясь к теме праведничества, унаследовала традиции русской агиографии, но применительно уже к героям нового типа. Это мирские люди, духовный подвиг которых не всегда имеет религиозную направленность, но реализует в себе стремление следовать евангельским заветам, которые выступали на первом месте в житийной литературе. Эти герои являют собой «память об идеале Древней Руси», говоря словами Л.В. Соколовой, применившей это выражение по отношению к произведениям авторов XX века, продолжившим традиции древнерусской литературы $[15,181]$. В данном случае уместно использование понятия «архетип праведника» для обозначения первичной устойчивой схемы, 
реализующейся в конкретных образах в процессе литературного творчества $[13,30]$.

В дилогии П.И. Мельникова-Печерского архетип праведника воплощается скорее не в религиозной форме, а в бытовой, «житийно-идиллической», по определению В.Е. Хализева $[18,115]$. Причем особое значение в формировании образа такого героя имел жанр жития, каноны которого в значительной степени определяли ход раскрытия образа. В наибольшей степени житийному канону соответствуют образы Дарьи Никитишны, крестной Насти Чапуриной, искусной поварихи, беззаветно преданной семье Патапа Чапурина, и Аграфены Петровны Заплатиной, «богоданной» дочери Чапурина, представленные однозначно положительно. Широкое использование приемов агиографической литературы в создании этих образов было отмечено В.А. Липатовым (См.: [9, 112-113]), по мнению которого, оно было возможным ввиду того, что второстепенные образы не требовали многогранности характеров, которая была несвойственна литературному этикету Древней Руси (см.: [9, 112], [10], [11]). Вообще, в житиях XIV - нач. XV века не было понятия характера как такового. Это отдельные эмоциональные состояния человека, относящие его однозначно либо к злым, либо к добрым, положительным или отрицательным персонажам (См.: $[11,72])$. Кроме того, по замечанию Д. С. Лихачева, этикетным нормам подчинялось поведение только положительных героев (См.: $[10,88])$.

П. И. Мельников-Печерский в построении образа праведника следует традиционной схеме жития, включая в повествование авторские вставки с целостной биографией героя-праведника - с рождения до момента встречи читателя с ним. В изображении жизненного пути праведника П.И. Мельникову-Печерскому важны те моменты, которые приближают его к образу древнерусского святого. Несмотря на схожесть основных моментов в биографии героев, жизнь их проходит по-разному.

Среди житий преподобных множество таких, в которых рассказывается о детстве святого (жития Феодосия Печерского, Авраамия Смоленского, Стефана Пермского, Сергия 
Радонежского, Кирилла Белозерского, Герасима Болдинского, Мартирия Зеленецкого и др.). Так, в дилогии П.И. Мельникова-Печерского Дарья Никитишна (Дарёнка), Аграфена Петровна (Груня) остаются в раннем в детстве сиротами, и это становится для них тяжелым испытанием. Зачастую рассказ о детстве святого сопровождается рассказом о его родителях, которые не всегда являются образцом для подражания. Если Груня с рождения была окружена родительской заботой и охраняема родительскими молитвами от тяжких невзгод даже после их смерти:

Так они ее любили, что ни за какие блага не покинули 6 в деревне с домовницей, чтоб потом, живучи в ярмарке, день и ночь думать и передумывать, не случилось ли чего недоброго с ненаглядной их дочуркой (II, 117)․․

Дарёнка же и при живых родителях и без них была несчастна, но

Мать хоть и пьяная и безумная, а высоко руку подымет, да не больно опустит, чужой же человек колотит дитя, не рассудя, не велика, дескать, беда, хоть и калекой станет век доживать (II, 87).

Святые, олицетворяя подобие Божие своими поступками и всем образом жизни, уже с раннего детства, иногда с самого рождения, несут на себе знак Божьей милости. Так и Груня в дилогии справляется с трудностями жизни в сиротстве с Божьей помощью: «святый божий покров всегда был над нею» (II, 117).

Подобно святым, которые сознательно избегали уже с детства веселых игр, мирских радостей, борясь с искушениями в непрестанном труде и нравственном совершенствовании, Дарья и Груня были лишены всего этого волею обстоятельств, которые вынуждают их привыкнуть к труду, самостоятельности. Если Груня не успела в полной мере испытать человеческое горе, оберегаемая Божьей милостью, то Дарья все детство и молодость провела в слезах, нескончаемых бедах и нищете, но обе удостоились благодарности за свои добродетели. Груня, как дважды подчеркивает П.И. Мельников-Печерский, по воле Бога, обрела родных в приемной 
семье Патапа Чапурина («взглянул Господь на сироту милосердным оком и послал к ней доброго человека» (II, 118)), а Дарья своим трудом заслужила спокойную старость и признание добрых людей, в том числе семейством Патапа Максимыча как лучшая повариха во всей округе.

Как святые преподобные оказывали помощь каждому приходящему человеку, так и обе героини сумели воздать миру своими добродетелями: Дарья Никитишна, заведя собственное хозяйство, дом, приютила троюродную племянницу и, воспитав ее как родную, обрела любящих ее дочь и внуков, а Аграфена Петровна, следуя словам Евангелия (Ин. 15:13), приведенным Патапом Максимычем: «Никто же больше тоя любви имать, аще кто душу свою положит за други своя...» (II, 123), и его совету воздать Богу молитвами, трудом и помощью бедным, решает призреть оставшихся без матери сирот и выходит замуж за овдовевшего Ивана Григорьевича Заплатина, пожилого, но доброго человека, с которым обретает семейное счастье. Сам Патап Максимыч видит в Грунином поступке некое подобие святости:

$<\ldots>$ такой любви к ближнему, такой жалости к малым сиротам не видывал, не слыхивал... Чистая, святая твоя душенька!..(II, 125).

Состояние покоя и умиротворения («Ясное, веселое лицо Аграфены Петровны верней всяких речей говорило, что нет у нее ни горя на душе, ни тревоги на сердце» (II, 116)), в котором пребывает Груня, передается окружающим ее людям:

$<. .>$ красным солнцем сияла она в мужнином доме, и куда вчуже ни показывалась, везде ей были рады, как светлому гостю небесному, куда ни войдет, всюду несет с собою мир, лад, согласье и веселье» (II, 116).

Сравнение Груни со «светлым гостем небесным» сродни устойчивому сочетанию, которое используется в житийном каноне по отношению к святым: «земные ангелы, небесные человецы».

Обе героини в земной, обычной мирской жизни совершают духовный подвиг, преодолев трудности, подобно святым, посвятившим свою жизнь служению Богу, добровольно выбирают путь служения миру, людям. Понятие праведности 
предполагает более широкий контекст, чем святость, не только религиозный. По замечанию С. Ю. Королевой, мирская праведность может привести человека к достижению святости, пусть и не гарантирует ее $[8,79]$. Герой-праведник в своем жизненном пути может быть не абсолютно идеальным, безгрешным, как святой. П.И. Мельников-Печерский, не идеализируя героинь, сосредоточивает внимание читателя только на положительных качествах в образах Дарьи Никитишны и Груни, даже не акцентируя внимания на том, что обе они принадлежат старообрядческой среде. Ему важно показать в образах героинь живое воплощение добродетелей, идеалов русской духовной культуры, носителями которой они являются, независимо от того, принадлежат ли они «древлеправославию» или господствующей церкви. Можно согласиться со справедливым замечанием И.А. Есаулова, что в текстах русской литературы (в данном случае на примере архетипа праведника) преломляется и определенным образом трансформируется христианская традиция, сформированная «греческим вероисповеданием» [5]. То, что П. И. Мельников-Печерский не делает положительные образы Дарьи Никитишны и Груни активными выразителями старообрядческого мировосприятия, свидетельствует об определенной позиции самого автора по отношению к старообрядчеству. Создавать положительный образ, тем более образ праведника, ревностно защищающего религиозную позицию старообрядчества по отношению к господствующей церкви, значило бы еще более укреплять разрыв между ними.

На наш взгляд, есть некоторое противоречие во взглядах исследователя В.В. Боченкова, который приводя слова П. И. Мельникова-Печерского из письма П. А. Валуеву: «А главный оплот будущего России все-таки вижу в старообрядцах, которые не будут раскольниками...» $[2,446]$, - высказывал мысль о том, что П.И. Мельников-Печерский стремился показать, что лучшие его герои могут быть старообрядцами, но не «раскольниками», а герои, сознательно стремящиеся в «раскол», всей душой преданные ему, могут быть только отрицательными. Однако образ игуменьи Комаровского скита Манефы входит в число положительных 
образов дилогии. И сам исследователь говорит о том, что в образе Манефы, всецело сроднившейся с религиозно-бытовой атмосферой старообрядчества, П. И. Мельников-Печерский воплотил национальный идеал (См.: $[2,446])$. В другой своей статье В.В. Боченков поясняет, что речь идет о старообрядцах, сохранивших национальные устои, национальный дух, который они передадут господствующей церкви, присоединившись к ней (См.: $[3,67])$, что, на наш взгляд, в случае с Манефой представляется маловероятным. Национальный идеал реализован скорее не в образе Манефы, требующем отдельного рассмотрения ввиду своей сложности, а в образах героинь-праведниц, Дарьи Никитишны и Аграфены Петровны Заплатиной, хотя, по замечанию Н. Г. Дергуновой, образ Дарьи Никитишны «проигрывает с социальной и интеллектуальной точки зрения» $[4,302]$.

Подобно этим героиням выстроен образ Марьи Гавриловны Масляниковой, молодой купеческой вдовы. Детство и юность, наполненные деспотизмом отца, потеря возлюбленного, неудачный брак со стариком, разочарование в любви Алексея Лохматого не разрушили цельный, исполненный добродетелями (главная из которых смирение) характер героини, но не идеальный: мысли ее полны мирским, земным.

Следует отметить, что образы праведниц Дарьи Никитишны, Аграфены Петровны, Марьи Гавриловны воскрешают тему святых жен в агиографической литературе, подвиг которых состоял не только в героическом воплощении добродетелей, но и в страдании как таковом. Можно провести типологическую параллель с таким памятником агиографической литературы, как Житие Юлиании Лазаревской, котоpoe, по замечанию Г.П. Федотова (См.: $[17,179])$, представляет не столько житие, сколько биографические записки о праведнице-мирянке, отличающиеся простотой, богатством бытового содержания. На ее долю выпало сиротство, насмешки за ее молитву и постничество уже в детстве, непонимание со стороны родственников и мужа ее благотворительной деятельности, голод, вдовство, после которого ее подвижничество приобретает более религиозный характер. Ее подвиг - 
подвиг смирения и любви, «дает понятие о том, как глубоко Евангелие могло войти в совесть и преобразить жизнь древнерусского человека» $[17,179]$. Но в отличие от героини древнерусской литературы, которая получила семейное и народное признание за свой подвиг любви только спустя десять лет после смерти, героини П.И. Мельникова-Печерского (не все) получают вознаграждение уже при жизни: признание и любовь людей («Добрая слава, хорошая слава!.. Дай Бог всякому такой славы, такой доброй по людям молвы!» (II, 128)) и вполне земную, материальную награду: Дарья Никитишна своим трудом накопила себе на спокойную старость, а Груня удвоила своим приданым достаток своего мужа.

К подобным героиням-праведницам также можно отнести Дарью Сергевну, тоже из старообрядческой среды. Ее жизненный путь во многом повторяет путь святых жен в Древней Руси. Сначала безродная сирота, затем безмужняя вдовица, «христова невеста», добровольно наложившая на себя обет безбрачия после пропажи жениха Мокея, брата Марко Данилыча Смолокурова, и, наконец, всецело посвятившая себя воспитанию Дуни, дочери Марко Данилыча. Она никогда не оставляла строгого поста и молитвы:

Незримо для людей ведя суровую жизнь строгой постницы, о доме и всем мире теплая молитвенница, Дарья Сергевна похудела, побледнела, но всегда прекрасно было крытое скорбью и любовью лицо ее, святым чувством добра и любви сияли живые, выразительные очи ее $(\mathrm{V}, 24)$.

Подвиг ее, с одной стороны, получает признание людей, а с другой - как часто бывает, оказывается немало злых языков, которые не верят в чистоту помыслов праведницы:

$<\ldots>$ были и прокаженные совестью, что, не веря чистым побужденьям, на подвижную жизнь ее метали грязными сплетнями. $<\ldots>$ Как можно было поверить, что молодая бедная девушка не захотела стать полноправной хозяйкой в доме такого богача?.. Как поверить, чтоб она из одной бескорыстной любви к безматерней сиротке решилась беззаветно посвятить ей дни свои $(\mathrm{V}, 24)$.

Дошедшие известия о слухах и сплетнях повергают искреннюю Дарью Сергевну в глубокие душевные пережива- 
ния, о которых не раз говорит автор на страницах дилогии («не испытанное еще ею доселе горе от клеветы» $(\mathrm{V}, 40)$ ): как стерпеть сплетни и обиды и не нарушить клятву, данную матери Дуняши, заменить сиротке родную мать? Автор открыто выражает свое сочувствие и симпатии незаслуженно обиженной героине.

Как и в случае с Дарьей Никитишной и Груней, П. И. Мельников-Печерский не подчеркивает принадлежность героини-праведницы к старообрядчеству. Она живет в христианской любви и смирении и так же воспитывает Дуню Смолокурову, не в строгости по правилам Домостроя, а в любви-милости, за что получает попреки. Мудрое решение Дарьи Сергевны отдать Дуню на воспитание по «древлему благочестию» в Манефину обитель и самой следовать за ней, чтобы не расставаться и заботливо оберегать ее вдали от смолокуровского дома, избавляет Дарью Сергевну от незаслуженной клеветы и попреков, идет на пользу самой Дуне и вызывает одобрение Марко Данилыча Смолокурова. За свой подвиг самоотречения Дарья Сергевна получает вознаграждение: все лучшее, что хотела вложить в Дуню, дало свои плоды, она счастлива счастьем своей воспитанницы; и спустя двадцать лет возвращается из неволи Мокей Данилыч. Дарья Сергевна остается верной обету, данному Богу, и потому советует Мокею забыть старое и самому обратиться к вере, вспомнить святоотеческие писания и примирить свою совесть с Господом (VII, 173), а сама держит мысль уйти в скиты, чтобы не смущать свою душу.

Усилие самоотречения раскрывает внутреннюю красоту героини, которая и была опоэтизирована П.И. Мельниковым-Печерским. Ее праведничество, как и праведничество Дарьи Никитишны, Груни, раскрывается в дилогии как черта национального русского характера, своеобразие которого удавалось сохранять старообрядцам и передавать из поколения в поколение.

Система женских образов праведниц может быть дополнена образом Дуни Смолокуровой, который объединил в себе и тему праведных жен, и тему духовного странничества в Древней Руси. В этом образе внешняя красота, 
проявившаяся с ранних лет, гармонично сочетается с внутренней $(\mathrm{IV}, 214)$. Дуня, оставшаяся без матери, росла в любви и ласке отца и Дарьи Сергевны, а затем получила воспитание в скиту по старинным обычаям благочестия, сохранившимся в старообрядческой среде:

Носила бы только в сердце страх Божий, да опасно хранила бы себя от мирских соблазнов... К родителю была бы почтительна, любовь бы имела к вам нелицемерную, повиновалась бы вам по бозе во всем, старость бы вашу, когда ее достигнете, чтила, немощь бы вашу и всякую скорбь от всея души понесла б на себе. Душевную бы чистоту хранила и бесстрастие телесное, от злых бы и плотских отлучалась, стыденьем бы себя украшала, в нечистых беседах не беседовала, а пошлет Господь судьбу - делала бы супругу все ко благожитию, чад воспитала бы во благочестии, о доме пеклась бы всячески, простирала бы руце своя на вся полезная, милость бы простирала к бедному и убогому и тем возвеселила бы дни своего сожителя и лета бы его миром исполнила $(\mathrm{V}, 58)$.

Автор акцентирует внимание на том, что отец Дуни хочет, чтобы в скиту ей привили общечеловеческие духовные ценности, а не воспитали «на чернецкую стать».

В Дуне сформировались такие качества, как скромность, искренность, необычайная любовь к близким:

Груня имела большое влияние на подраставшую девочку, ее да Дарью Сергевну надо было Дуне благодарить за то, что, проживши семь лет в Манефиной обители, она всецело сохранила чистоту душевных помыслов и внедрила в сердце своем стремление к добру и правде, неодолимое отвращенье ко всему лживому, злому, порочному (V, 60).

Бесконечная любовь к Дуне со стороны отца, тонкая духовная связь с ним прививают ей чувство семейственности как одну из основополагающих ценностей культуры. Своими мыслями о семье и любви Дуня делится со скитскими девушками, и слова ее не по-юношески мудры и тверды:

Кого по мысли найду, за того и пойду, и буду любить его довеку, до последнего вздоха, - одна сыра земля остудит любовь мою... <..> Знаю одно: где муж да жена в любви да совете, по добру да 
по правде живут, в той семье сам Господь живет. Он и научит меня, как поступать... (IV, 254).

Своими представлениями о жизни, вере, любви Дуня приближается к типу святых жен Древней Руси, но, в отличие от предыдущих героинь-праведниц, на ее долю не выпадает страданий, ее праведничество - в живом воплощении добродетелей.

Мирская праведность не предполагает абсолютной безгрешности. Доверчивость, впечатлительность Дуни, а также временное разочарование в своих идеалах приводят девушку в хлыстовскую секту. Здесь можно говорить о другом типе праведничества, духовном странничестве, сформированном также в Древней Руси. Пребывание Дуни в среде хлыстов в поисках истины, вызвавшее охлаждение к своим родным, дому, вере, все же не сломало ее внутреннего стержня. Духовное странничество Дуни заканчивается тогда, когда к ней возвращаются мысли о заботливом отце и приходит осознание ложности того учения, которое она приняла:

Чего искала, чего хотела?.. Истинной веры?.. Вот и узнала. Тот же туман, тот же мрак, что и у матушки Манефы в скиту (VI, 409).

Несмотря на все угрозы со стороны хлыстов, Дуня сумела решительно отказаться от этого учения, что свидетельствует о нравственной силе героини. Пересилив свою неприязнь к великороссийской церкви, она принимает помощь от «никонианского» попа Прохора, который становится духовным наставником юной девушки. И здесь она не забывает старинные заветы древлего православия:

Обливаясь слезами, до земли она преклонилась пред своим избавителем, но благословения не приняла - все-таки ведь он никониан (VII, 13).

В конце дилогии показано преображение героини, вызванное сильными эмоциональными потрясениями: бегство из «корабля людей Божиих», как называли себя хлысты, и смерть любимого отца. Дуня кается Богу за то, что предалась ложному учению. Она, как никогда начинает ценить близких ей людей, а после смерти отца становится самостоятельной, полноправной хозяйкой, благодарной каждому, кто 
помог ей в трудную минуту. Наконец, добродетельность героини вознаграждается - сбываются ее слова, сказанные однажды в разговоре со скитскими девушками о замужестве: Дуня обретает взаимную любовь в лице Петра Самоквасова. Показательно то, что героиня, к положительному образу которой автор испытывает симпатии, решает венчаться в великороссийской церкви, а не у беглого священника. Сначала это объясняется принадлежностью Дуни к спасову согласию, на которое она указывает в разговоре с отцом Прохором:

Мы по спасову согласию, не чуждаемся и приемлющих священство, - отвечала Дуня. - Крестят у нас и свадьбы венчают в великороссийской, а хоронят по-своему, по старине значит, отдельные кладбища для того отведены (VI, 440).

Спасовцы - одно из беспоповских старообрядческих согласий, сторонники которого считали, что спастись можно только уповая на Спаса (Христа). Они, не считая возможным совершать таинства крещения и брака, допускали возможность обращения для совершения этих таинств в официальную церковь (См.: [21, 1203]). Однако к решению венчаться Дуня и Петр приходят уже сознательно, убедившись в правоте великороссийской церкви в результате осмысления сущности веры. К этому подталкивают Дуню и беседы с православным попом Прохором и с Герасимом Силычем Чубаловым, познавшим много вероисповеданий в своих скитаниях. Как поясняет Дуне отец Прохор:

Все же вы единую с нами веру исповедуете, разнствуете токмо в обрядах, да вот еще духовного чиноначалия отрицаетесь (VI, 441).

Дуня Смолокурова представляет героев-старообрядцев нового типа, молодое поколение, которое видит сущность веры не только во внешней форме, обрядовости, но и в глубоком осмыслении духовных ценностей. Это поколение старообрядцев, способное сохранить национальное своеобразие от влияния иных культур, но при этом оторваться от мертвых религиозных догм. Не случайно Дуня Смолокурова в дилогии воплощает «идеальный образ, от которого веет чем-то национально-чистым», говоря словами Н. А. Ян- 
чука $[22,203]$. Ее образ выражает ориентацию П.И. Мельникова-Печерского на духовные идеалы древнерусской литературы.

Архетип праведника, реализуемый через тему духовного странничества, может быть также представлен образом Герасима Силыча Чубалова, которому посвящена не одна глава романа «На горах». Биография этого героя, как и других значимых персонажей дилогии, дается П.И. Мельниковым-Печерским во всей полноте, без нарушения временной последовательности, начиная с детства героя и рассказа о его семье. Такая особенность построения образа проявляется, как видим, и на примере других героев, в которых раскрывается архетип праведника. Это свойство писательской манеры не раз отмечалось исследователями (Л. М. Лотман, В.А. Липатов и др.).

Подобно святым в житийной литературе, которые встречали препятствие со стороны родителей (Феодосий Печерский, Кирилл Белозерский), Герасим с детства проявляет тягу и необычайные способности к учению вопреки недовольству отца и условиям крестьянской жизни, где в первую очередь от подрастающего поколения требовались рабочие руки, а не ученая голова:

Побои не отвадили от книг тринадцатилетнего мальчика; чем больше его били, тем прилежней он читал их, и притом всякая работа больше да больше ему противела (V, 439).

Герасим, подобно христианским праведникам, стойко выносит испытания.

Как и в случае с Дуней Смолокуровой, перед которой в нужный момент появляется наставница Алымова, чтобы своими беседами и нужным книгами склонить молодой пытливый ум в хлыстовщину, Герасим выбирает своим духовным наставником деревенского книжника, начетчика из спасова согласия. Постепенно Герасим сводит круг общения к одному лишь начетчику, тихому, незлобивому, смиренному постнику, а затем и вовсе, начитавшись житий христианских подвижников, решает стать отшельником и «провести свои дни до скончания живота в подвигах, плоть изнуряющих, дух же возвышающих» $(\mathrm{V}, 440)$. Герасим отделяется 
от внешнего мира и создает свое внутреннее пространство, которое некоторыми исследователями определяется как парадигма вывернутого вглубь себя пространства внешнего мира, характерного для литературы Древней Руси (См.: [15, 182]).

В своих представлениях о религиозном подвиге, об истинной вере, счастье Герасим Чубалов первоначально схож с главным героем раннего рассказа П.И. Мельникова-Печерского «Гриша». Оба героя, следуя своим ложным представлениям о вере, не подкрепленным глубоким духовным содержанием, пускаются на поиски истинной веры. Снова, как и в рассказе «Гриша», в дилогии возникает сквозной образ пустыни-матери, символизирующий для героев счастье и спасение души и вызывающий желание повторить подвиг христианского подвижника Варлаама (V, 441). Герасим, как и Гриша, испытывает умиление и счастье в своем отчужденьи. Оба героя в своем стремлении постичь истинную веру доходят до религиозного аскетизма, опустошающего их душу («Это был сухой аскет, все человеческое было ему чуждо» (V, 445)).

Можно говорить об устойчивом мотиве испытания праведничества. Если в Грише некогда праведническое начало в результате заблуждения приводит его к окончательному безверию и преступлению, в котором теряется смысл подвижничества, то образ Герасима, лишенный обличительно-сатирического оттенка, получает свое развитие. Проходя в поисках правой веры через множество старообрядческих согласий и толков, но находя везде противоречия, Герасим отрекался и вновь пускался на поиски, которые закончились глухой нетовщиной ${ }^{2}$, п правой веры все-таки не нашел:

И в душевном отчаянье, в злобе и ненависти покинул он странство (V, 445).

Странствия в поисках истинной веры сменяются деятельностью «старинщика» - поисками старинных книг, икон, церковной утвари. Вновь в связи с образом Чубалова П. И. Мельников-Печерский поднимает тему сохранения культурного наследия дониконовской Руси, поднятую еще в романе «В лесах» и в «Очерках поповщины». В результате бездумной 
европеизации терялась ценность старины. В стороне от этого влияния оказались старообрядцы, сохранявшие дух исконной Руси: «<...> в середине XIX в. старообрядчество явилось своеобразной охранной грамотой русской идеи» $[20,37]$. П. И. Мельников-Печерский увидел своего рода подвиг в настойчивой деятельности «старинщиков»-старообрядцев по спасению старины от «легкоумия обезьянствовавших баричей». И одним из таких спасателей в дилогии показан Герасим Силыч Чубалов.

С этого начинается духовное возрождение героя. Поначалу корыстные мотивы побуждают Герасима побывать в родной стороне, похвастаться перед родителем, как он грамотеем нажил богатство, но чувство гордыни оказывается сломлено:

$<\ldots>$ черствое сердце сурового отреченника от людей и от мира дрогнуло при виде братней нищеты и болезненно заныло жалостью $(\mathrm{V}, 451)$.

В душе героя происходит переворот («У Герасима сердце повернулось» $(\mathrm{V}, 459))$. Сначала в очерствевшем сердце героя проявляется жалость, сострадание к семье брата и осознание напрасно проведенных пятнадцати лет в скитаниях по свету в поисках истины, а истина оказалась рядом:

$<\ldots>$ вот она где правая-то вера, а в странстве да в отреченье от людей и от мира навряд ли есть спасенье... (V, 452).

Внутренние монологи героя о смысле веры, милости, свидетельствуют о духовном перерождении героя. Этот переворот в герое связан, на наш взгляд, с сильной ориентацией П.И. Мельникова-Печерского на древнерусскую традицию, на духовно-нравственные идеалы Древней Руси.

Праведническое начало в Герасиме, проявившееся еще в детстве, но на время угасшее в результате ложных представлений героя о вере, находит свое развитие. Герасим всецело посвящает себя жертвенному служению семье брата, положив себе завет жить одной семьей с братом, «друг друга тяготы носити» $(\mathrm{V}, 477)$ (те же слова будут сказаны в дилогии от лица Патапа Максимыча: «Друг друга тяготы носите и тем исполните закон Христов» (VI, 365)). Потратив все свое нако- 
пленное богатство на восстановление обедневшего хозяйства и на освобождение от рекрутчины сыновей брата, Герасим обрел вдвое больше - смысл жизни, счастье быть семьянином и чувствовать благодарность родных. К нему приходит осознание евангельской истины «Бог есть любовь», преображающей душу человека:

Такую отраду, такое высокое духовное наслаждение почувствовал он, каких до тех пор и представить себе не мог... <...> «Бог есть любы», - благоговейно и много раз повторял в ту ночь Герасим Силыч (V, 478).

Любовь, добрые дела, труд не только духовно обогащают Герасима Силыча, но и возвращают ему материальное богатство. Дуня Смолокурова, которой Герасим помог в трудную минуту, щедро вознаграждает его.

В этом герое-праведнике наиболее полно воплотились представления П. И. Мельникова-Печерского о высшей правде человеческого существования, смысл которого не в религиозном аскетизме, а в подвижничестве, исполненном евангельских истин.

П. И. Мельников-Печерский показывает героев, в которых реализовался архетип праведника, преимущественно в старообрядческой среде, сохраняющей в большей степени идеалы Древней Руси, патриархальные основы жизни. Однако это вовсе не значит, что в дилогии отсутствуют герои праведнического типа в нестарообрядческой среде (Сергей Андреич Колышкин, перешедший в великороссийскую церковь, православный поп Прохор, знахарка Егориха). Главным критерием праведничества для писателя становится не принадлежность героя к старообрядчеству или господствующей церкви, не следование религиозным догмам и обрядам, а живая душа героя, способная к любви и состраданию. Поэтому герои-праведники из старообрядческой среды не являются открытыми выразителями идеологии старообрядцев, в некоторых случаях Мельников-Печерский даже не делает акцента на принадлежности героя старой вере. Герои, к которым автор испытывает наибольшие симпатии, прежде всего являются выразителями христианского мироощущения. 


\section{Примечания}

Исследование выполнено в рамках государственного задания Минобрнауки России (ГБТ N 651-14).

1 Здесь и далее цитаты приводятся по изданию: Мельников П. И. (Андрей Печерский). Собр. соч.: В 8 т. М.: Правда, 1976. В круглых скобках указывается номер тома и страницы.

2 Глухая нетовщина - один из толков спасовского беспоповского старообрядческого согласия, представители которого видели спасение в уповании и молитвах Спасу (Христу) («Слезами крестил себя Герасим, в умилении стоя перед Спасовым образом»). Название «глухая нетовщина» объясняется тем, что вместо пения на богослужениях читались Псалтырь и каноны (См.: Шахов М. О. Спасовское согласие // Энциклопедия религий / Под ред. А.П.Забияко, А.Н. Красникова, Е.С. Элбакян. М.: Академический проект; Гаудеамус, 2008. С. 1203).

\section{Список литературы}

1. Боченков В.В. Творчество П.И. Мельникова-Печерского и изображение старообрядчества в русской литературе XIX века: Дис. ... канд. филол. наук / Лит. ин-т им. А. М. Горького. М., 2005. 179 с.

2. Боченков В. В. «А главный оплот будущего России все-таки вижу в старообрядцах»: Новый взгляд на старообрядчество в творчестве П.И. Мельникова-Печерского // Старообрядчество в России (XVIIХХ вв.): Сб. науч. тр. Вып. 4 / Отв. ред. и сост. Е. М. Юхименко. М.: Языки славянских культур, 2010. С. 428-449.

3. Боченков В. В. «Писатель с некоторым пристрастным отношением к расколу»: особенности создания художественного характера старообрядца в произведениях П.И. Мельникова (Андрея Печерского) // Старообрядчество в Тверском крае. Прошлое и настоящее. Материалы круглого стола, состоявшегося в Тверском гос. ун-те 16 февраля 2007 г. Тверь, Ржев, 2007. С. 65-72.

4. Дергунова Н.Г. Православные ценности в художественном воплощении в романе П.И. Мельникова-Печерского «В лесах» // Русское православие как основа сохранения национальной идентичности. XVI Рождественские православно-философские чтения. Н. Новгород, 2007. С. 299-302.

5. Есаулов И.А. Обвинительная филология // Литература. 2008. № 20 [Электронный ресурс]. Режим доступа: http://lit.1september.ru/article. php?ID=200802027 
6. Кудрямов И. В. Русская литература в поисках духовной самоидентификации: национальная жизнь в изображении П.И. Мельникова-Печерского, Н. С. Лескова, В. Г. Короленко, Г. И. Успенского: Автореф. дис. ... доктора филол. наук. Волгоград: Волгоградский гос. пед. ун-т, 2008. $35 \mathrm{c}$.

7. Кудряшов И. В. К вопросу о философской проблематике романа-дилогии П.И. Мельникова-Печерского «В лесах» и «На горах» // Православие и русская литература: Материалы Всероссийской науч.-практ. конф. «Православие и русская литература. Вузовский и школьный аспект изучения» г. Арзамас, 22-24 мая 2003 г. Арзамас: АГПИ, 2004. С. 69-74.

8. Королева С. Ю. Образ праведника в «деревенской прозе» В. Распутина (К вопросу о художественном воплощении народной религиозности) // Вест. Пермск. ун-та. Пермь, 2009. Вып. 1: Российская и зарубежная филология. С. 79-89.

9. Липатов В.А. Житие и сказ (о соотношении устной и письменной традиции в романе П.И. Мельникова «В лесах» // Русская литература 1870-1890 годов. Свердловск, 1977. С. 106-115.

10. Лихачев Д. С. Поэтика древнерусской литературы. М.: Наука, 1979. $376 \mathrm{c}$.

11. Лихачев Д. С. Человек в литературе Древней Руси. М.: Наука, 1970. $180 \mathrm{c}$.

12. Николаева Е.В. Перечитывая эпопею Мельникова-Печерского // Литература в школе. 1999. № 7. С. 26-34.

13. Пьхтина Ю. Г. К проблеме использования пространственной терминологии в современном литературоведении // Вест. Оренбург. унта. 2013. № 11 (160). С. 29-36.

14. Смирнова Н.Н. Концепция праведничества в повести В.Г. Распутина «Последний срок» // Вестник ТГПУ. 2010. Вып. 8 (98). С. 122-126.

15. Соколова Л. В. «Житийный» персонаж как выражение авторского идеала в произведениях писателей-традиционалистов (В. Шукшин, В. Белов, В. Астафьев, В. Распутин) // Русская литература XIX-XX веков: проблемы теории и методологии изучения: Мат-лы II Международ. науч. конф (16-17 ноября 2006 г.). М.: Изд-во МГУ, 2006. C. $181-185$.

16. Тарасова С.А. Поэтико-аксиологический аспект творчества П.И. Мельникова-Печерского: на материале дилогии «В лесах» и «На горах»: дис. ... канд. филол. наук / Тамб. гос. ун-т им. Г. Р. Державина. Мичуринск, 2009. $202 \mathrm{c}$.

17. Федотов Г. П. Собр. соч.: в 12 т. М.: Мартис, 2000. Т. 8: Святые Древней Руси. 268 с. 
18. Хализев В. E. «Герои времени» и праведничество в освещении русских писателей XIX века // Русская литература XIX века и христианство: Сб. ст. М.: Изд-во МГУ, 1997. С. 111-119.

19. Хализев В.Е. Лесковская концепция праведничества // В мире Лескова: Сб. ст. / Сост. В.А. Богданов. М.: Советский писатель, 1983. C. $196-232$

20. Царегородиева С. С. Старообрядчество в романах П.И. Мельникова-Печерского и Г.Д. Гребенщикова // Алтайский текст в русской культуре. Барнаул, 2004. Вып. 2. С. 34-41.

21. Шахов М.О. Спасовское согласие // Энциклопедия религий / Под ред. А.П. Забияко, А.Н. Красникова, Е.С. Элбакян. М.: Академический проект; Гаудеамус, 2008. Стб. 1203.

22. Янчук Н. А. Павел Иванович Мельников (Андрей Печерский) // История русской литературы XIX века / Под ред. Д. Н. Овсянико-Куликовского. М.: Изд. Т-ва «Мир», 1910. Т. 4. С. 194-207.

\section{Lyubov Viktorovna Alekseeva}

Master of Arts of the Faculty of Philology's Web-Laboratory, Petrosavodsk State Unversity

(Petrosavodsk, Russian Federation)

lempi@mail.ru

\section{IMAGES OF OLD BELIEVERS IN PAVEL MELNIKOV-PECHERSKY'S DILOGY IN THE WOODS AND ON THE HILLS}

Abstract. The article examines an archetype of the righteous person in the Pavel Melnikov-Pechersky's dilogy through the example of Old Believers images which form the main part of the text. Through the example of righteousness as a subject the interconnection Melnikov-Pechersky's dilogy with Old Russian literature traditions, focused on Christian values, is shown. Russian literature of the 19th century, which kept these traditions addressing to the subject of righteousness, created heroes of a new type. These are secular people, imperfect and a bit sinful, but holding onto the ideals of Old Russia. Such righteous persons being the ambodiment of different virtues are portrayed in Melnikov-Pechersky's dilogy. The article draws some typological parallels with Old Russian literature and identifies several types of righteous heroes in the dilogy - certain types of righteous women and spiritual wanderers. As a result, on the basis of the analysis of Old Believers' images it can be concluded that the main criterion of righteousness for Pavel MelnikovPechersky is not belonging of the hero to the Old Belief or to the dominating church but his/her Christian attitude and following evangelical precepts. 
That is why Melnikov-Pechersky does not present the righteous Old Believers as active spokesmen of the Old Belief ideology.

Keywords: image, Old Believer, righteous person, tradition, Old Russian literature, national ideal, spiritual values

\section{References}

1. Bochenkov V. V. Tvorchestvo P. I. Mel'nikova-Pecherskogo i izobrazhenie staroobryadchestva $v$ russkoy literature XIX veka. Diss. kand. filol. nauk [P. I. Melnikov-Pechersky's Creative Work and the Image of the Old Belief in Russian Literature of the 19th Century. PhD philol. sci. diss.]. Moscow, The Maxim Gorky Literature Institute Publ., 2005. 179 p.

2. Bochenkov V. V. "A glavnyy oplot budushchego Rossii vse-taki vizhu v staroobryadtsakh»: Novyy vzglyad na staroobryadchestvo v tvorchestve P. I. Mel'nikova-Pecherskogo ["And I See the Main Stronghold of the Future of Russia after All in the Old Believers»: A New View on the Old Belief in P. I. Melnikov-Pechersky's Creative Work]. Staroobryadchestvo $v$ Rossii (XVII-XX veka) [The Old belief in Russia (17-20th Centuries)]. Moscow, Yazyki slavyanskikh kul'tur Publ., 2010, issue 4, pp. 428-449.

3. Bochenkov V. V. «Pisatel' s nekotorym pristrastnym otnosheniem $\mathrm{k}$ raskolu»: osobennosti sozdaniya khudozhestvennogo kharaktera staroobryadtsa v proizvedeniyakh P. I. Mel'nikova (Andreya Pecherskogo) [«The writer with Some Prejudice to Raskol»: the Features of Creating the Fictional Character of an Old Believer in P. I. Melnikov's (Andrey Pechersky's) Works]. Staroobryadchestvo $v$ Tverskom krae. Proshloe $i$ nastoyashchee [The Old Belief in Tver Region. The Past and the Present]. Tver, Rzhev, 2007, pp. 65-72.

4. Dergunova N.G. Pravoslavnye tsennosti $v$ khudozhestvennom voploshchenii v romane P. I. Mel'nikova-Pecherskogo «V lesakh» [Orthodox Values in the Artistic Realization in P. I. Melnikov-Pechersky's Novel «In the Woods»]. Russkoe pravoslavie kak osnova sokhraneniya natsional'noy identichnosti. XVI Rozhdestvenskie pravoslavno-filosofskie chteniya [Russian Orthodoxy as the Basis of the Preservation of National Identity. The 16th Christmas Orthodox and Philosophical Readings]. Nizhny Novgorod, 2007, pp. 299-302.

5. Esaulov I.A. Obvinitel'naya filologiya [Accusatory Philology]. Literature [Literatura]. 2008, no 20. Available at: http://lit.1september.ru/article. php?ID=200802027 (accessed 3 October 2014).

6. Kudryashov I.V. Russkaya literatura $v$ poiskakh dukhovnoy samoidentifikatsii: natsional'naya zhizn' v izobrazhenii P. I. Mel'nikovaPecherskogo, N. S. Leskova, V. G. Korolenko, G. I. Uspenskogo. Avtoref. kand. filol. nauk [Russian Literature in Search of Spiritual Self- 
Identification: National Life in P. I. Melnikov-Pechersky's, N. S. Leskov's, V. G. Korolenko's, G.I.Uspensky's portrayal. PhD philol. sci. diss. abstract]. Volgograd, Volgograd State Pedagogical University Publ., 2008. 35 p.

7. Kudryashov I. V. K voprosu o filosofskoy problematike romana-dilogii P. I. Mel'nikova-Pecherskogo «V lesakh» i «Na gorakh» [Philosophical Perspective of P. I. Melnikov-Pechersky's Dilogy «In the Woods» and «On the Hills»]. Pravoslavie i russkaya literatura [Orthodoxy and Russian Literature]. Arzamas, Arzamas State Pedagogical Institute Publ., 2004, pp. 69-74.

8. Korolyova S. Yu. Obraz pravednika v «derevenskoy proze» V. Rasputina (K voprosu o khudozhestvennom voploshchenii narodnoy religioznosti) [The Image of a Righteous Person in V. Rasputin's Creative Work (Christian and Folk Elements in Russian Village Prose)]. Vestnik Permskogo universiteta [Perm State University Bulletin]. Perm, 2009, issue 1, pp. 79-89.

9. Lipatov V.A. Zhitie i skaz (o sootnoshenii ustnoy i pis'mennoy traditsii v romane P. I. Mel'nikova «V lesakh» [Hagiography and Narration (the Corellation of an Oral and a Written Tradition in P. I. Melnikov's Novel «In the Woods»]. Russkaya literatura 1870-1890 godov [Russian literature of 1870-1890s]. Sverdlovsk, 1977, pp. 106-115.

10. Likhachev D.S. Poetika drevnerusskoy literatury [Poetics of Old Russian Literature]. Moscow, Nauka Publ., 1979. 376 p.

11. Likhachev D.S. Chelovek v literature Drevney Rusi [The Person in the Literature of Old Russia]. Moscow, Nauka Publ., 1970. 180 p.

12. Nikolaeva E.V. Perechityvaya epopeyu Mel'nikova-Pecherskogo [Re-reading Melnikov-Pechersky's Epic Work]. Literatura $v$ shkole [Literature in the School], 1999, no. 7, pp. 26-34.

13. Pykhtina Yu. G. K probleme ispol'zovaniya prostranstvennoy terminologii v sovremennom literaturovedenii [The Use of Spatial Terminology in the Contemporary Literary Studies]. Vesnik Orenburgskogo universiteta [Orenburg University Bulletin], 2013, no. 11 (160), pp. 29-36.

14. Smirnova N.N. Kontseptsiya pravednichestva v povesti V. G. Rasputina «Posledniy srok» [The concept of Righteousness in Valentin Rasputin's Novel «The Last Term»]. Vestnik Tomskogo gosudarstvennogo pedagogicheskogo universiteta [Tomsk State Pedagogical University Bulletin]. 2010, issue 8 (98), pp. 122-126.

15. Sokolova L. V. «Zhitiynyy» personazh kak vyrazhenie avtorskogo ideala v proizvedeniyakh pisateley-traditsionalistov (V. Shukshin, V. Belov, V. Astaf'ev, V. Rasputin). [The character of Hagiography as an Expression of an Author's Ideal in the Works of Traditionalist Writers (V. Shukshin, V. Belov, V. Astafyev, V. Rasputin)]. Russkaya literatura XIX-XX vekov: 
problemy teorii i metodologii izucheniya [Russian literature of the 19th and 20th Centuries: Problems of the Theory and Methodology of Studying]. Moscow, Moscow State University's Publ., 2006, pp. 181-185.

16. Tarasova S. A. Poetiko-aksiologicheskiy aspekt tvorchestva P. I. Mel'nikovaPecherskogo: na materiale dilogii «V lesakh» $i$ «Na gorakh». Diss. kand. filol. nauk [Poetical and axiological aspect of P. I. Melnikov-Pechersky's Creative Work Through the Example of His Dilogy "In the Woods" and "On the Hills". PhD. philol. sci. diss.]. Michurinsk, 2009. 202 p.

17. Fedotov G. P. Sobranie sochineniy: $v 12$ tomakh [Collected Works in 12 Vols.]. Moscow, Martis Publ., 2000. Vol. 8: Saint of Ancient Russia. $268 \mathrm{p}$.

18. Khalizev V. E. «Geroi vremeni» i pravednichestvo v osveshchenii russkikh pisateley XIX veka [«Heroes of Time» and Righteousness Portrayed by Russian Writers of the 19th Century]. Russkaya literatura XIX veka $i$ khristianstvo [Russian Literature of the 19th Century and Christianity]. Moscow, Moscow State University's Publ., 1997, pp. 111-119.

19. Khalizev V. E. Leskovskaya kontseptsiya pravednichestva [Leskov's Concept of Righteousness]. V mire Leskova [In Leskov's World]. Moscow, Sovetskiy pisatel' Publ., 1983, pp. 196-232.

20. Tsaregorodtseva S. S. Staroobryadchestvo v romanakh P. I. Mel'nikovaPecherskogo i G. D. Grebenshchikova [The Old Belief in the Novels of P. I. Melnikov-Pechersky and G. D. Grebenshchikov]. Altayskiy tekst $v$ russkoy kul'ture [The Altai Text in the Russian Culture]. Barnaul, 2004, issue 2, pp. 34-41.

21. Shakhov M. O. Spasovskoe soglasie [Saviour Consent]. Entsiklopediya religiy [Encyclopedia of Religions]. Moscow, Akademicheskiy proekt Publ.; Gaudeamus Publ., 2008, pp. 1203.

22. Yanchuk N. A. Pavel Ivanovich Mel'nikov (Andrey Pecherskiy) [Pavel Ivanovich Melnikov (Andrey Pechersky)]. Istoriya russkoy literatury XIX veka [History of Russian Literature of the 19th Century]. Moscow, Mir Publ., 1910, vol. 4, pp. 194-207. 